\title{
SELEÇÃO COMPORTAMENTAL POR CONSEQUÊNCIAS
}

\author{
BEHAVIORAL SELECTION BY CONSEQUENCES
}

\author{
JAY MOORE
}

\author{
UNIVERSITY OF WISCONSIN-MILWAUKEE, ESTADOS UNIDOS
}

\begin{abstract}
RESUMO
Como um processo, seleção consiste em (a) variação de características, (b) interação diferencial com o ambiente com base na variação de características e (c) replicação diferencial de características benéficas, adaptativas, na forma de sua transmissão para, e expressão em, futuras gerações de uma população. A análise do comportamento sugere que a seleção se aplica à análise do comportamento de um organismo tanto quanto a uma análise de sua morfologia e da origem da espécie. Os três níveis aos quais analistas do comportamento aplicam o princípio de seleção são (a) filogenético, para o desenvolvimento de um repertório inato em uma espécie; (b) ontogenético, para o desenvolvimento de um repertório operante durante o tempo de vida de um organismo individual; e (c) cultural, para o desenvolvimento de práticas culturais em um grupo social. Grande parte da psicologia tradicional está comprometida em postular causas antecedentes do comportamento, particularmente quando se supõe que tais causas são mentais. Este artigo argumenta que uma ciência do comportamento está bem servida ao dispensar interesses em causas mentais antecedentes em favor da seleção por consequências como modo causal.
\end{abstract}

Palavras-chave: B. F. Skinner, análise do comportamento, Charles Darwin, evolução, seleção por consequências

\section{ABSTRACT}

Selection as a process consists of (a) variation of traits, (b) differential interaction with the environment on the basis of the variation of traits, and (c) differential replication of beneficial, adaptive traits in the form of their transmission to and expression in future generations of a population. Behavior analysts suggest selection applies to the analysis of an organism's behavior just as much as to an analysis of its morphology and the origin of species. The three levels at which behavior analysts apply the principle of selection are (a) phylogenic, for the development of an innate repertoire in a species; (b) ontogenic, for the development of an operant repertoire in the lifetime of an individual organism; and (c) cultural, for the development of cultural practices in a social group. Much of traditional psychology is committed to postulating antecedent causes of behavior, particularly where those causes are assumed to be mental. This article argues that a science of behavior is well-served by setting aside concerns with antecedent mental causes in favor of selection by consequences as a causal mode.

Key words: B. F. Skinner, behavior analysis, Charles Darwin, evolution, selection by consequences

\footnotetext{
Este artigo foi derivado de material que desenvolvi ao longo dos anos para auxiliar em meu próprio ensino sobre o tópico de seleção por consequências na análise do comportamento. Eu o ofereço aqui na esperança de que outros o considerem útil. Atendendo ao objetivo instrucional do artigo, referências foram mantidas ao mínimo. Adicionalmente, tanto a linguagem quanto os argumentos são mais informais do que em outros artigos. Se falhei na execução, peço desculpas e peço a tolerância do leitor. Posso apenas dizer que as contingências ainda não terminaram comigo.

Correspondência relativa ao artigo deve ser endereçada ao autor em jcm@uwm.edu, ou ao seu endereço residencial: 1861 E. Fox Lane; Fox Point, WI 53217; USA.
}

Tradução: Alexandre Dittrich, Universidade Federal do Paraná. Nota do tradutor: Quando relevante, as palavras originalmente usadas pelo autor foram colocadas entre colchetes após sua tradução. 
Em seu emblemático livro On the Origin of Species (A Origem das Espécies, 1859) Charles Darwin buscou explicar como espécies podem surgir, se desenvolver ou se extinguir. Seus princípios explanatórios mais importantes foram seleção e evolução, ambos derivados de uma orientação naturalista em relação às ciências da vida. Esses princípios desafiaram aqueles derivados de uma orientação religiosa, como os que supunham que um agente divino criou espécies com um conjunto essencial de atributos, e que as espécies surgiam, se desenvolviam ou se extinguiam por intervenção divina. Embora a seleção e a evolução tenham sido inicialmente controversas, ambas são agora firmemente aceitas na comunidade científica. Como o geneticista Theodosius Dobzhansky (1964) notoriamente afirmou, "Nada na biologia faz sentido exceto à luz da evolução" (p. 449). Antecipando a segunda metade da presente exposição, vale também notar as palavras relacionadas do neurobiólogo Gordon Shepherd (1988): "Nada na neurobiologia faz sentido exceto à luz do comportamento" (pp. 6-7).

Em seu sentido mais geral, a seleção consiste em um ciclo contínuo e repetitivo de três aspectos. $\mathrm{O}$ primeiro aspecto é variação aleatória e intrínseca em uma ou mais características ou propriedades fisiológicas dos organismos em uma população. Um termo sinônimo, comumente usado para tais características ou propriedades, é traços. Na linguagem de hoje, uma fonte de variação são as mutações aleatórias que ocorrem naturalmente quando as células de linha germinativa (ovos, esperma) se desenvolvem nos genitores e ocorrem erros quando o DNA que forma os genes em tais células se reproduz ou se copia. As mutações não se devem a uso ou desuso durante a vida dos genitores.

O segundo aspecto é a interação diferencial entre as características dos organismos e circunstâncias ambientais prevalentes. Aqui, o sentido de interação diz respeito a quão bem as características de um organismo permitem a ele fazer frente às demandas do ambiente material, ou quão bem suas características lhe permitem obter recursos para a manutenção da vida, dada a presença de outros organismos, por exemplo, com quem ele compete pelos mesmos recursos. O sentido de diferencial é que certas características conferem certas vantagens adaptativas ou benefícios aos organismos que as possuem. Quanto mais fortes são as características vantajosas, mais forte se diz que é a aptidão [fitness] dos organismos. Quanto maior a aptidão dos organismos, maior a probabilidade de que sobrevivam, dadas as circunstâncias ambientais prevalentes. A ausência das características relevantes não confere tais vantagens adaptativas. Talvez a presença de outras características seja até mesmo desadaptativa. Organismos sem as características vantajosas ou com características desadaptativas são menos adaptados. Esses organismos não conseguem competir com organismos mais adaptados por recursos para a manutenção da vida. Como resultado, é baixa a probabilidade de que os organismos menos adaptados sobrevivam.

O terceiro aspecto é a replicação diferencial das características adaptativas, vantajosas, em gerações futuras da população. Aqui, os organismos sobreviventes - aqueles com as características vantajosas - acasalam e produzem prole. Por sua vez, essa prole acasala e produz sua própria prole, e assim por diante. O sentido de replicação é que as características vantajosas são transmitidas para e expressas em sucessivas gerações de descendentes, e uma linhagem é estabelecida entre tais gerações. O sentido de diferencial é que organismos com as características vantajosas, ao invés daqueles sem tais características, são os que contribuem com descendentes para as futuras gerações e constituem a linhagem. Organismos sem as características vantajosas, ou com características desadaptativas, não sobrevivem, não se reproduzem, e obviamente não contribuem com descendentes para as futuras gerações. Ao invés disso, eles se extinguem.

Como resultado da replicação diferencial, o número, ou porcentagem de organismos na população com características vantajosas aumenta progressivamente, enquanto o número, ou porcentagem de organismos sem tais características ou com características desvantajosas diminui progressivamente. Neste sentido, a taxa de aumento e diminuição é uma função da taxa de variação na população.

Em verdade, as características dos membros da população continuam a sofrer mutações durante o tempo evolucionário, e mutações adicionais podem tornar as características ainda mais vantajosas. Se as mutações forem de fato mais vantajosas, elas se acumularão ao longo do tempo, conforme sejam transmitidas para, e expressas em, futuras gerações, de modo consistente com os benefícios adaptativos que confiram aos organismos em tais gerações. Esses organismos são o próximo passo na linhagem. Novamente, se as mutações forem desadaptativas os organismos não sobrevivem, e suas características obviamente não são replicadas.

Um último ponto é que em alguns casos, organismos com as características vantajosas podem produzir prole, mas ela não é fértil. Obviamente, essa prole não-fértil não contribui com descendentes para futuras gerações da população, e não estabelece uma linhagem. Como um exemplo, jumentos machos normalmente acasalam com jumentas fêmeas. Essas uniões produzem mais jumentos e jumentas. Cavalos machos normalmente acasalam com éguas fêmeas. Essas uniões produzem mais cavalos e éguas. Nos dois casos, as proles são férteis e contribuem para suas 
respectivas espécies. Em contraste, jumentos machos podem acasalar com éguas fêmeas. Essas uniões produzem mulas. Neste caso, a prole não é fértil, não contribui para uma espécie e não estabelece uma linhagem.

Em suma, o ciclo repetitivo de (a) variação, (b) interação diferencial e (c) replicação diferencial ocorre ao longo de períodos muito longos do tempo evolucionário. Espécies emergem quando as características dos organismos contribuem para que eles se adaptem ao ambiente, quando, por exemplo, permitem aos organismos ocupar um nicho ecológico que existe em um período e local particulares. De acordo com muitos biólogos, esses organismos então produzem proles férteis apenas com organismos semelhantes. Essas proles férteis marcam o estabelecimento de uma linhagem. De qualquer modo, espécies não são criadas ou planejadas com um conjunto de características fixo, imutável e perfeito. Espécies se extinguem quando circunstâncias ambientais mudam mais rapidamente ao longo do tempo do que as características dos organismos sofrem mutações, ou quando as características originalmente vantajosas dos organismos sofrem mutações de modo a não ser mais vantajosas, dadas as circunstâncias ambientais prevalentes. Como sugerido acima, a aptidão de um organismo é uma questão de quão bem suas características contribuem para a adaptação às circunstâncias ambientais prevalentes. A aptidão não implica a existência de algum estado de perfeição fixo e pré-determinado, em relação ao qual as características atuais de um organismo seriam uma aproximação.

\section{SELEÇÃO POR CONSEQUÊNCIAS: MORFOLOGIA E ESPECIAÇÃO}

Um cenário relativo ao desenvolvimento do tamanho e formato do bico de um pássaro pode ajudar a ilustrar o processo cíclico da seleção. Comecemos supondo que numa dada região, digamos que relativamente cedo no tempo evolucionário, muitos tipos de sementes estão disponíveis, das quais uma população de pássaros pode se alimentar. Devido à disponibilidade de tantos tipos de sementes, bicos de um tamanho e formato particular não conferem vantagem adaptativa no que se refere a quebrar e consumir tais sementes. Como resultado, ocorre uma considerável variação quanto ao tamanho e formato do bico entre os membros da população de pássaros. Contudo, e de interesse para a presente exposição, com respeito a um tipo de semente - por simplicidade, vamos chamá-la semente A - pássaros com bicos de um tamanho e formato particulares levam vantagem sobre pássaros com bicos de outros tamanhos e formatos: Os primeiros conseguem imediatamente consumir a semente A, enquanto os últimos não conseguem. Novamente, no início desse cenário, digamos que cedo no tempo evolucionário, essa vantagem não produz consequências relevantes, dado que o segundo tipo de pássaro pode consumir outras sementes e sobreviver perfeitamente bem.

Em seguida, suponhamos que o clima muda nessa região. Como resultado, a semente A se torna predominante na região, e outras sementes se tornam menos disponíveis. Os pássaros com bicos que lhes permitam consumir a semente $\mathrm{A}$ então têm uma probabilidade mais alta de sobreviver do que os outros pássaros, que não conseguem consumir a semente $\mathrm{A}$. Seus bicos não são melhores em nenhum sentido absoluto, mas meramente mais adequados com respeito às circunstâncias ambientais que existem naquele momento do que os bicos de outros pássaros. Essa relação ilustra o segundo aspecto da seleção: interação diferencial entre circunstâncias ambientais prevalentes e as características dos organismos. Novamente, se as circunstâncias fossem diferentes, por exemplo, se uma semente diferente da A tivesse se tornado dominante, bicos de um tamanho e formato diferentes poderiam ser mais vantajosos.

O terceiro aspecto da seleção é a replicação diferencial. Esse aspecto envolve a transmissão de características vantajosas para futuras gerações da população e a expressão de tais características nessas gerações. Em outras palavras, ao longo do tempo, os pássaros com bicos vantajosos sobrevivem, se reproduzem e transmitem suas características à sua prole, que por sua vez expressa tais características. De especial importância, tais pássaros começam a aumentar em número, como consequência de seu acesso às sementes. Talvez futuras mutações no tamanho e formato dos bicos dos pássaros ao longo do tempo evolucionário se mostrem ainda mais adaptativas, e o aumento seja ainda maior. Em contraste, pássaros com bicos de tamanho e formato diferentes - uma característica não adaptativa ou possivelmente até desadaptativa - começam a diminuir em número, como consequência de sua dificuldade em encontrar sementes que possam consumir. De qualquer modo, o resultado é o surgimento de uma população de pássaros com bicos que tendem a apresentar um tamanho e formato particulares.

Darwin tinha dúvidas sobre o mecanismo ou processo biológico da replicação, embora tenha especulado sobre entidades chamadas "gêmulas". Gêmulas seriam estruturas muito pequenas que ele imaginou que circulavam dentro do corpo de um organismo. Conforme circulassem, elas absorveriam certas características do organismo. Por sua vez, as células de linha germinativa absorveriam as gêmulas e as transmitiriam à prole na concepção. As gêmulas então circulariam na prole, que absorveria e expressaria as características. De modo interessante, as gêmulas de Darwin permitiriam a transmissão tanto de 
características inatas quanto adquiridas dos genitores, que se expressariam na prole. A ideia de que características adquiridas poderiam ser transmitidas para e expressas na prole se baseava nas ideias do biólogo francês Jean Baptiste Lamarck. Era uma noção controversa na época de Darwin, mas ele quis prestar-lhe reconhecimento. A história da genética revela que aproximadamente no mesmo período Mendel demonstrou que a replicação era ordenada e particulada, embora seu trabalho tenha permanecido relativamente desconhecido até ser redescoberto perto do fim do século 19. Pesquisas posteriores mostraram que as características dos genitores eram às vezes, embora não sempre, misturadas na prole, e características adquiridas não eram replicadas na prole. Ao longo do fim do século 19, DeVries e Bateson, entre outros, redescobriram e expandiram o trabalho de Mendel, criando as bases para Morgan, Dobzhansky, e a "Grande Síntese" na segunda e terceira décadas do século 20, que aprofundou a identificação dos princípios do mecanismo biológico subjacente à replicação. Em meados do século 20, Watson e Crick identificaram o mecanismo molecular da replicação, envolvendo a estrutura química do DNA como base para o gene.

Assim, organismos que estão vivos hoje podem proveitosamente ser compreendidos como pertencendo a uma linhagem de sobreviventes. A linhagem se desenvolveu ao longo do tempo evolucionário, conforme circunstâncias ambientais selecionaram certas características dos ancestrais dos sobreviventes. As características então variaram ao longo de várias gerações. Conforme as características variavam, o ambiente selecionou ou rejeitou as variações. Variações que foram adaptativas e vantajosas contribuíram para a sobrevivência dos ancestrais, significando que aqueles ancestrais, e não outros, produziram proles férteis com organismos semelhantes, e gerações futuras consistiram de seus descendentes. Os membros dessas futuras gerações podem ser entendidos como descendentes com modificações de seus ancestrais, e as modificações se acumularam ao longo de sucessivas gerações. $\mathrm{O}$ processo é chamado "seleção natural" quando o ambiente seleciona alguns organismos que sobrevivem, e outros organismos que se extinguem, com base na presença ou ausência de certas características. O processo é chamado "seleção sexual" quando organismos de um certo sexo concedem acesso reprodutivo a organismos de outro sexo porque são receptivos às características (e.g., morfológicas) do outro sexo. Essas características são então transmitidas para e replicadas na prole, tornando-se proeminentes em futuras gerações. O processo é chamado "seleção artificial" (e.g., "reprodução seletiva") quando humanos intervém deliberadamente fazendo acasalar organismos com (ou alternativamente, sem) certas características para produzir futuras gerações com (ou alternativamente, sem) tais características. Exemplos comuns são animais de fazenda que são criados para botar mais ovos ou para produzir mais leite ou mais carne, ou para ser mais dóceis como animais de carga.

Neste sentido, uma definição comum de uma espécie entre biólogos é (a) uma população reprodutivamente isolada de organismos com (b) proles férteis, embora essa definição seja com frequência debatida por suas limitações. Por exemplo, algumas espécies se reproduzem assexuadamente. Na verdade, a reprodução sexuada é vantajosa, dado que uma das características variáveis que pode ser replicada é a resistência a doenças ou patógenos. Adicionalmente, suponha que um organismo da espécie $X$ acasala com um organismo da espécie Y, e sua prole não é fértil. Em seguida, suponha que um organismo da espécie Y acasala com um organismo da espécie $\mathrm{Z}$, e sua prole não é fértil. $O$ que acontece quando um organismo da espécie $\mathrm{X}$ acasala com um organismo da espécie Z? A expectativa é presumivelmente que a prole não seja fértil, não estabeleça uma linhagem e não seja uma espécie. Contudo, em alguns casos, a prole é fértil. Assim, uma definição abrangente de uma espécie ainda é necessária.

O conceito de contingência é central para a compreensão da seleção. $\mathrm{Na}$ linguagem cotidiana, o termo "contingência" implica uma relação "se..., então...", sendo a relação condicional ou probabilística ao invés de certa ou logicamente necessária. Em outras palavras, se certas condições ou eventos ocorrerem, então a probabilidade de um efeito ou consequência específicos é maior do que se aquelas condições ou eventos não ocorrerem. Inversamente, se aquelas condições ou eventos não ocorrerem, então a consequência pode ser diferente, ou talvez nada aconteça, mas pelo menos a probabilidade da consequência específica é menor do que se as condições ou eventos ocorrerem. No caso da morfologia de um organismo e da origem das espécies, a interação diferencial significa que a consequência descrita acima sobrevivência ou extinção - é probabilisticamente contingente à, ou probabilisticamete dependente da, relação entre as características do organismo e as circunstâncias ambientais prevalentes. Nem a sobrevivência, nem a extinção são um resultado necessário baseado unicamente na presença ou ausência de certas características do organismo.

Finalmente, nota-se que quando o ambiente seleciona as características de um organismo, algumas dessas características são a base ou os critérios para a seleção, ao passo que algumas características vêm junto com o organismo simplesmente porque são parte de sua dotação. A distinção é entre "seleção para" versus "seleção de". A primeira diz respeito a algumas características específicas que são base ou critério para a seleção. A segunda diz respeito a características que são 
efeitos colaterais da seleção. Considere-se a população de pássaros previamente mencionada. Os pássaros são selecionados pelo tamanho e formato dos seus bicos, que conferiram aos pássaros a habilidade de consumir a semente A. Suponhamos agora que os pássaros que têm bicos que lhes permitiram consumir a semente $\mathrm{A}$ também tendam a ter penas vermelhas. Os dois atributos - bicos e penas - covariaram, mas apenas um - seus bicos - serviu de base para a seleção. Podemos dizer, de modo mais útil, que houve seleção de, mas não seleção para, penas vermelhas, no sentido de que as cores das penas dos pássaros foram o efeito colateral do processo de seleção, ao invés de seu alvo. Como frequentemente se afirma, correlação não implica causação. Essa distinção é relevante porque alguns atributos dos organismos podem ter participado do processo de seleção, mas apenas como efeitos colaterais, e pesquisadores e teóricos podem subsequentemente ter equivocadamente identificado esses atributos como alvos.

\section{SELEÇÃO POR CONSQUÊNCIAS: COMPORTAMENTO}

A presente tese é de que o princípio de seleção é tão relevante para o desenvolvimento do repertório comportamental de um organismo quanto é para o desenvolvimento da morfologia de um organismo, por meio de descendência com modificações, acumulação dessas modificações e por fim a origem das espécies. De fato, os organismos interagem com o ambiente por meio de seu comportamento. Darwin, na verdade, reconheceu a possibilidade da evolução comportamental em vários de seus trabalhos, como On the Origin of Species (A Origem das Espécies, Darwin, 1859), The Descent of Man (A Descendência do Homem, Darwin, 1871) e The Expression of the Emotions in Man and Animals (A Expressão das Emoções no Homem e nos Animais, Darwin, 1872). As emoções lhe eram de especial interesse, porque Darwin pensava que elas refletiam uma continuidade não apenas da evolução comportamental, mas também mental. Contudo, ele não escreveu tão extensivamente sobre evolução comportamental e mental quanto sobre morfologia e especiação via seleção natural.

Com respeito ao comportamento, podemos identificar três níveis aos quais a seleção por consequências se aplica: filogenético, ontogenético e, para humanos, cultural. O nível filogenético refere-se ao desenvolvimento de comportamentos específicos das espécies [species-specific behavior] durante o tempo de vida das espécies. O nível ontogenético refere-se ao desenvolvimento e manutenção de formas mais flexíveis de comportamento durante o tempo de vida de um organismo individual. $O$ nível cultural refere-se ao desenvolvimento e manutenção de práticas sociais durante o tempo de vida de um grupo. Podemos dizer que tanto o comportamento humano quanto o não-humano são selecionados pela interação com o ambiente nos níveis filogenético e ontogenético. Reconhecendo que o assunto é muito debatido, para os presentes propósitos restringiremos a seleção no nível cultural aos humanos. Podemos agora examinar de modo mais próximo o processo de seleção comportamental por consequências e o papel das contingências em cada um desses níveis.

\section{SELEÇÃO COMPORTAMENTAL POR CONSEQUÊNCIAS: O NÍVEL FILOGENÉTICO}

O primeiro nível de seleção comportamental por consequências é o nível filogenético. Novamente, esse nível diz respeito à seleção de respostas inatas e específicas da espécie pela interação com o ambiente durante o tempo de vida da espécie. Suponhamos que no passado havia uma população de organismos. Mais uma vez, para os presentes propósitos os organismos podem ser humanos ou não-humanos. Suponhamos ainda que tais organismos apresentaram respostas que foram eliciadas ou liberadas [released] por estímulos ou aspectos do ambiente. Em seguida, suponhamos que embora estímulos antecedentes tenham eliciado ou liberado as respostas, algumas das respostas podem ainda trazer um benefício adaptativo. Isto é, respostas com certas características beneficiaram o organismo e por fim a espécie, porque as respostas conferiram uma vantagem para a sobrevivência. Alguns desses benefícios podem ter sido diretamente para os organismos e a espécie: obter alimento, evitar predadores. Alguns desses benefícios podem ter sido indiretos para a espécie: atrair parceiros, construir ninhos, cuidar da prole. De qualquer modo, houve uma contingência entre as respostas e a sobrevivência. Se as respostas de um organismo com respeito ao ambiente possuíam as características necessárias, então a probabilidade de que aquele organismo ou sua prole tenham sobrevivido foi maior do que se as respostas do organismo não possuíssem tais características. Se o organismo sobreviveu, então foi mais provável que se reproduzisse. Se ele se reproduziu, então foi mais provável que sua prole e descendentes em futuras gerações fossem organismos nos quais as características comportamentais adaptativas, vantajosas, foram replicadas. O resultado foi o desenvolvimento de uma espécie com um repertório inato - o estabelecimento de uma linhagem comportamental.

Por exemplo, organismos cujos batimentos cardíacos aumentavam durante encontros com predadores estiveram melhor preparados para sobreviver, porque os batimentos cardíacos aumentados permitiram a esses organismos escapar melhor de tais predadores. Organismos que piscavam diante de rajadas de vento que sopravam perto de objetos perigosos para seus olhos estiveram melhor preparados para sobreviver, 
porque piscar protegeu seus olhos e preservou sua visão. Organismos que salivavam diante de alimento estiveram melhor preparados para sobreviver, porque podiam engolir e metabolizar melhor o alimento. Organismos que construíam ninhos para sua prole, por exemplo, em períodos particulares do ano indicados pela temperatura, elevação do sol, e assim por diante, estiveram melhor preparados para proteger sua prole. Organismos que anunciavam sua disponibilidade como potenciais parceiros, não apenas por meio de aparência visual, mas também por meio de vocalizações ou de comportamentos rituais para outros da mesma espécie que estivessem receptivos a tais características, tiveram maior probabilidade de se reproduzir. Assim, tais características foram diferencialmente transmitidas à prole e diferencialmente expressas em futuras gerações da população. Em contraste, respostas que não tivessem tal vantagem podiam até mesmo ser desadaptativas. Organismos com respostas desadaptativas pereceram. Assim, nem tais organismos nem suas respostas com tais características foram replicadas no futuro. De modo geral, estamos falando aqui sobre a contraparte comportamental da seleção natural. O resultado é que o número de organismos aumenta ou diminui como função de suas características comportamentais.

Devemos acrescentar uma advertência: Esse processo é benéfico contanto que o ambiente não mude apreciavelmente. Se o ambiente muda, então respostas ligadas ao antigo ambiente podem não ser mais úteis, e a sobrevivência do organismo que persiste em tais respostas pode estar em risco.

Em termos gerais, podemos usar a frase "contingências de sobrevivência" para falar sobre as contingências comportamentais que selecionaram organismos com certas respostas no nível filogenético, tanto por seleção natural quanto sexual. Podemos agora chamar tais respostas inatas de respondentes, e de certas formas ou padrões adicionais de comportamento liberado, específico da espécie. As contingências operaram talvez ao longo de centenas de milhões de anos de evolução, durante o "tempo de vida" evolucionário da espécie conforme ela evoluiu. As respostas contribuíram para a sobrevivência dos organismos que as possuíam. As respostas inatas foram replicadas - transmitidas à prole que então as expressou - por meio da genética do organismo. Novamente, quando consideradas ao longo do tempo evolucionário, essas respostas constituem uma linhagem comportamental. Os mecanismos genéticos que replicam o comportamento inato neste nível são estudados pela genética comportamental. As relações entre comportamento e circunstâncias ambientais que evocam o comportamento inato são estudadas pela etologia e pela psicologia comparada.

\section{SELEÇÃO COMPORTAMENTAL POR}

\section{CONSEQUÊNCIAS: O NÍVEL ONTOGENÉTICO}

O segundo nível de seleção comportamental por consequências é o nível ontogenético. Como apontamos, este nível de seleção refere-se ao desenvolvimento e manutenção de respostas por meio da interação com o ambiente durante o tempo de vida do organismo individual. As principais respostas de interesse neste nível são operantes.

No caso dos operantes, suponhamos que durante o tempo de vida de um organismo individual, o organismo apresentou uma população aleatoriamente variada de movimentos. Esses movimentos foram simplesmente "emitidos", ao invés de eliciados ou liberados por estímulos ou circunstâncias específicas do ambiente, como ocorre no nível filogenético. Afinal, uma das características de estar vivo é o movimento. Talvez os termos comuns "aleatório" ["random"] e "espontâneo" ["spontaneous"] possam ser aplicados convenientemente a tais variações de movimento ao longo do tempo. De modo geral, essa característica é a de variação, no mesmo sentido em que variações na morfologia se aplicam a organismos ao longo do tempo.

Além disso, suponhamos que movimentos com algumas características foram seguidos por certos resultados, tais como certos estímulos ou eventos, que não teriam ocorrido de outro modo. Essa característica é a de interação diferencial. Alguns desses resultados podem mesmo ter envolvido o acesso a recursos para a manutenção da vida ou a esquiva de predadores, mas eles podem ter tido outros resultados críticos também.

Continuando, suponhamos que os movimentos que foram seguidos pelos estímulos ou eventos acima mencionados se tornam mais frequentes. Esse aumento de frequência é análogo à replicação e por fỉm à sobrevivência de uma espécie. Visando desenvolver um relato coerente, chamemos agora tais movimentos de "respostas" ["responses"] e as condições, eventos ou estímulos que são consequências das respostas de "reforços" ["reinforcers"]. Novamente, alguns dos reforços podem mesmo ter estado relacionados às necessidades biológicas do organismo, e portanto à sua sobrevivência. Contudo, nem todos os reforçadores estiveram relacionados a necessidades biológicas. De qualquer modo, eles ainda tiveram o efeito chamado reforçador [reinforcing]. Respostas com outras características que não foram seguidas por tais estímulos ou eventos podem ter sido contraprodutivas. Essas respostas se tornaram menos frequentes, analogamente à extinção de uma espécie. Assim, houve uma contingência entre as respostas e certos estímulos ou eventos no ambiente que tais respostas produziram: Se a resposta com as características apropriadas foi emitida, então o estímulo ou os eventos se seguiram como resultado. $\mathrm{O}$ efeito foi um aumento na frequência das respostas que tiveram tais consequências no contexto [setting] no qual as respostas ocorreram. Podemos 
designar as contingências que selecionaram tais respostas, que agora podemos chamar de respostas operantes, como "contingências de reforço". Essas contingências atuaram durante o tempo de vida do organismo individual. $\mathrm{O}$ aumento no responder que resultou das contingências é a replicação diferencial. As respostas foram transmitidas para o futuro por meio do sistema nervoso do organismo, que foi modificado durante a interação com o ambiente chamada reforço. Os mecanismos fisiológicos neste nível de acordo com os quais as consequências modificam o comportamento que ocorre em um certo contexto - os mecanismos pelos quais os reforços aumentam o comportamento que os produz, e (adotando metaforicamente a linguagem da genética) os mecanismos que transmitem e expressam o comportamento - são estudados pela neurociência comportamental: plasticidade sináptica e assim por diante. As experiências com eventos ambientais, as variáveis e as relações que selecionam o comportamento neste nível são estudadas pela análise do comportamento: ratos pressionando barras, pombos bicando chaves, o andar e o falar em humanos.

Um processo chamado modelagem [shaping] é às vezes responsável pelo desenvolvimento de operantes. A modelagem é análoga à seleção artificial. Em linguagem mais formal, a modelagem envolve o reforçamento diferencial de aproximações sucessivas a alguma forma final desejada de comportamento alvo. Aqui, suponha que um humano dispensa uma consequência reforçadora após a resposta de outro organismo, humano ou não-humano, de modo contingente a tal resposta se mostrar sucessivamente mais próxima ao comportamento desejado. A modelagem é um processo planejado, no sentido de que depende de outro organismo, como um humano, para dispensar o reforço, assim como a seleção artificial é um processo planejado no sentido de que depende de humanos que façam acasalar organismos com características desejadas para produzir prole com essas mesmas características, ou talvez características ainda mais desejáveis.

Em princípio, operantes podem também se originar de comportamentos eliciados ou liberados, dado que tais formas de comportamento podem ter consequências durante o tempo de vida imediato do organismo. A questão é se o controle da resposta muda da eliciação antecedente original para a seleção por consequências. O problema é empírico, e deve ser resolvido caso a caso considerando as espécies, as circunstâncias eliciadoras e as respostas.

O nível ontogenético é o nível do tempo de vida do organismo individual, em virtude de suas experiências com o ambiente. Respostas operantes claramente são um componente importante da seleção comportamental neste nível. Embora muitas formas de comportamento operante possam se desenvolver tanto em espécies quanto entre espécies, o controle operante não se desenvolve para cada resposta de cada organismo.

Também relevantes, como talvez um caso especial no nível ontogenético, são as respostas por condicionamento clássico, nas quais um estímulo originalmente neutro correlacionado com um estímulo incondicionado passa a eliciar uma resposta no mesmo sistema de respostas, assim como o estímulo incondicionado. Embora vários cenários sejam possíveis, uma possibilidade é que este processo tenha se originado como um benefício para um organismo por prepará-lo para um estímulo incondicionado iminente. A ampla variedade de estímulos, respostas e organismos envolvidos neste processo comprovam os vários nichos ecológicos que organismos ocuparam ao longo do tempo evolucionário por meio da ação seletiva do ambiente.

\section{SELEÇÃO COMPORTAMENTAL POR CONSEQUÊNCIAS: O NÍVEL CULTURAL}

O terceiro nível de seleção comportamental por consequências é o nível cultural. Novamente, esse nível envolve a seleção de práticas culturais por meio da interação com o ambiente durante o tempo de vida de um grupo social. Esse nível se aplica particularmente talvez até mesmo exclusivamente - a humanos de uma certa geração ou entre gerações, e a um certo grupo ou a diferentes grupos. Suponhamos que conforme os humanos começaram a viver em grupos sociais, os grupos desenvolveram certas práticas grupais para lidar com aspectos importantes de suas vidas. Essas práticas podem ter tido relação com agricultura, irrigação, domesticação e criação de animais, religião, proteção de recursos naturais, produção de energia, descarte de resíduos, manufatura, economia e o tratamento dispensado aos outros no grupo - idosos, jovens, doentes, carentes. Em suma, o interesse aqui é sobre as formas de fazer coisas que o grupo como um todo adota. Suponhamos que intra- ou entre gerações, dentro do mesmo grupo ou entre diferentes grupos, instâncias das práticas se distinguam por suas características aleatoriamente variáveis. Essa característica é a variação.

Adicionalmente, suponhamos que algumas dessas práticas tenham uma consequência benéfica. Isto é, práticas com certas características habilitaram o grupo a resolver problemas ou lidar efetivamente com desafios do ambiente. Essas práticas contribuíram para o bem estar do grupo, e talvez até mesmo para sua sobrevivência. Tais práticas podem ser vistas como formas especiais de comportamento operante, no sentido de que elas têm consequências, mas elas se aplicam à cultura como um todo, ao invés de apenas a um único organismo. Práticas com outras características não necessariamente contribuem na mesma extensão para o 
bem estar e a sobrevivência do grupo. Algumas práticas podem até mesmo ser contraprodutivas, mas passaram a existir por outras razões, tal como ser socialmente aprovadas mesmo que seu impacto material fosse negativo. Um grupo que se engajasse em práticas contraprodutivas estaria em perigo, e poderia se extinguir, a menos que mudasse seus hábitos. Assim, houve uma contingência entre práticas culturais e o bem-estar final do grupo, quando não sua sobrevivência: se os membros do grupo se engajaram em certas práticas, então o grupo como um todo esteve mais preparado para se adaptar ao seu ambiente e sobreviver. Se os membros do grupo se engajaram em outras práticas, então o grupo como um todo esteve menos preparado para se adaptar ao seu ambiente e sobreviver. O grupo pode ter se extinguido. Essa característica é a de interação diferencial em relação ao ambiente.

Quando a cultura sobreviveu, suas práticas foram replicadas por meio dos arranjos sociais entrelaçados do grupo e transmitido a futuras gerações por meio de sua linguagem. Tais práticas foram então expressas em futuras gerações. Essa característica é a de replicação diferencial.

Podemos designar as contingências que selecionaram tais práticas, que agora podemos chamar de uma "cultura", como "contingências de evolução cultural". Essas contingências atuaram durante o tempo de vida da cultura. O argumento aqui é que as práticas culturais são análogas a respostas no repertório de um organismo, no sentido de que elas se desenvolveram e mantiveram na relação com circunstâncias ambientais. Práticas culturais não são avaliadas por alguma escala absoluta, com as práticas assim chamadas primitivas de selvagens e bárbaras na extremidade inferior e as práticas assim chamadas avançadas dos países colonizadores industrializados da Europa e América do Norte na extremidade superior, como sugeria o que foi chamado de "Darwinismo Social". Assim como respostas no repertório de um organismo não são caracterizadas com tais termos, as práticas culturais também não são. $\mathrm{Na}$ verdade, muitas práticas são perigosas e contraprodutivas, como são outras formas de comportamento. Contudo, a questão relevante é quão bem tanto as respostas individuais quanto as práticas culturais contribuem para a adaptação e em última análise para o bem estar e até mesmo a sobrevivência da cultura. Porém, soluções a essa questão dependem da relação entre as respostas e práticas, por um lado, e as circunstâncias ambientais prevalentes - particularmente os resultados das respostas e práticas, por outro. As soluções não derivam de afirmações sobre superioridade ou inferioridade intelectual intrínseca dos organismos envolvidos. Os mecanismos que replicam práticas culturais neste nível são estudados pela antropologia social e cultural.

\section{SUMÁRIO E CONCLUSÕES}

Assim como estruturas internas como genes são centrais para a compreensão da seleção morfológica e da especiação por meio de descendência com modificações, também os genes e o sistema nervoso do organismo que se comporta são centrais para a compreensão da seleção comportamental por consequências e do desenvolvimento de repertórios. Os genes de um organismo obviamente participam na variação de características e propriedades do comportamento do organismo. O papel dos genes é o de uma receita, não o de um destino, ou um conjunto de instruções, não um projeto específico [blueprint]. Voltemo-nos para o nível ontogenético. Um organismo que em virtude de sua dotação genética tenha uma receita para um suprimento maior de comportamento independente [uncommited] e uma maior suscetibilidade a reforços do que outros organismos tem uma vantagem adaptativa sobre esses outros organismos. Mudanças no sistema nervoso de um organismo como consequência das experiências do organismo com o ambiente, como quando o comportamento operante se desenvolve, são análogas a mutações na dotação genética do organismo dos genitores para a prole. A linguagem é responsável pela replicação de certas práticas culturais no nível cultural em humanos. As mudanças no sistema nervoso humano que resultaram no potencial de controle operante sobre o comportamento verbal são particularmente dignas de nota porque muito do que é unicamente humano se segue dessas mudanças. Contudo, um organismo que não se comportou em relação ao ambiente não sobreviveu, e não deixou descendentes no mundo atual, no qual estamos interessados. Tantos os genes quanto o sistema nervoso de um organismo tornam o comportamento adaptativo possível, e eles próprios são aspectos evoluídos da vida.

Explicações do comportamento na psicologia tradicional tipicamente apelam a vários atos, estados, mecanismos e processos de um domínio não-comportamental - tipicamente mental ou cognitivo como causas antecedentes, mecânicas, seja como causas organísmicas iniciadoras ou mediadoras, no estilo do behaviorismo mediacional S-O-R. Devido a tradições históricas e culturais, essas causas organísmicas foram consideradas inobserváveis, mas pesquisadores e teóricos as tornaram cientificamente respeitáveis ao designá-las como "construtos hipotéticos" e defini-las operacionalmente. A tese da seleção oferece uma abordagem inteiramente diferente para entender as causas do comportamento. Essa abordagem se baseia em conceitos naturalistas da biologia: adaptação, seleção, contingências e assim por diante. Essa abordagem alternativa produz, em última análise, uma compreensão mais efetiva do comportamento.

Atualmente, pesquisadores e teóricos debatem vários aspectos relativos à seleção. Um deles é unidade 
de seleção. Seria a unidade o próprio gene, o organismo individual ou um grupo total de organismos? Em relação à seleção no nível cultural, seria útil considerar que pequenos padrões de organização e interação social ("memes") são replicados entre uma cultura, assim como pequenos aspectos da morfologia são replicados entre uma população de organismos? Há pouco consenso em tais debates, o que na ciência geralmente implica que o caminho está aberto para que o pensamento criativo os resolva.

Concluindo, vemos que para humanos, a seleção comportamental por consequências atua ao longo de três níveis: filogenético, ontogenético e cultural. O processo consiste de (a) variação; (b) interação diferencial com o ambiente; e (c) replicação diferencial do comportamento, por meio de sua transmissão para e expressão no futuro. Nos três níveis, há indivíduos que apresentam formas variáveis de (a) respostas inatas, (b) respostas emitidas e (c) práticas culturais. Nos três níveis, a natureza da interação envolve (a) sobrevivência das espécies, (b) reforço e (c) solução de problemas das culturas, em última análise levando em geral ao seu bem estar e sobrevivência. Nos três níveis, a replicação diferencial do comportamento é efetivada por meio de (a) genética, (b) modificações no sistema nervoso e (c) linguagem. O processo é cíclico e se repete ao longo do tempo, conforme o ambiente interage com a população e, por sua vez, as características da população mudam. Além disso, o ambiente que realiza a seleção também pode mudar. $\mathrm{O}$ comportamento inato e as respostas operantes contribuem para a aptidão comportamental de um indivíduo, dependendo de quão prontamente elas contribuem para a adaptação às contingências em um dado ambiente. Similarmente, práticas culturais contribuem para a aptidão de uma cultura, dependendo de quão prontamente as práticas contribuem para a adaptação às contingências em um dado ambiente, particularmente em relação à sobrevivência. Se o ambiente muda, uma resposta inata, uma resposta operante ou uma prática cultural anteriormente apta pode não ser mais útil para a espécie, o indivíduo ou a cultura. De fato, a resposta anteriormente apta pode na verdade atuar contra o bem estar ou a sobrevivência da espécie, do indivíduo ou da cultura. Assim, a aptidão comportamental pode ser entendida como condicional às circunstâncias prevalentes em um dado ambiente, em um dado tempo, assim como a aptidão morfológica. $\mathrm{O}$ comportamento não é nem bom nem mau em um sentido absoluto, e também não mostra um planejamento proposital. Além disso, pode haver misturas das contingências entre os três níveis. Um organismo pode se comportar agressivamente como resultado de influências filogenéticas, ontogenéticas ou culturais. Animais domesticados que puxam um arado ou uma carroça, ou que pastoreiam gado, exibem um conjunto complexo de influências ao longo dos níveis filogenético e ontogenético. A abordagem em sua totalidade torna a psicologia, como uma ciência do comportamento, uma parte intrínseca da biologia, em virtude da sustentação em comum na seleção por consequências como modo causal.

Palavras e frases importantes: Evolução, seleção por consequências, seleção natural, seleção sexual, seleção artificial, variação, interação diferencial, replicação diferencial, transmissão, expressão, características, descendência com modificação, linhagem, mutações, aptidão, lamarckismo, nível filogenético, eliciação, formas liberadas de comportamento específico da espécie, nível ontogenético, operantes, respondentes condicionados, nível cultural, práticas culturais, espécie, reforço, sobrevivência, extinção, morfologia, modelagem, contingência, contingência de reforço, contingência de sobrevivência, gene, genética comportamental, etologia, análise do comportamento, antropologia cultural, seleção de, seleção para.

\section{REFERENCIAS}

Darwin, C. (1859). On the origin of species by means of natural selection, or the preservation of favoured species in the struggle for life. London: Murray.

Darwin, C. (1871). The descent of man. London: Murray.

Darwin, C. (1872). The expression of the emotions in man and animals. London: Murray.

Dobzhansky, T. (1964). Biology, molecular and organismic. American Zoologist, 4(4), 443-452.

Shepherd, G. (1988). Neurobiology ( $2^{\text {nd }}$ ed.). Oxford: Oxford University Press.

Submetido: $28 / 03 / 2018$ Aceito: $21 / 04 / 2018$ 